\title{
BUDIDAYA IKAN NILA DIBANTARAN SUNGAI MALI-MALI SEBAGAI PENINGKATAN PRODUKSI EKONOMI MASYARAKAT
}

\author{
M.Hadi Nur \\ Fakultas Keguruan dan Ilmu Pendidikan, Universitas Lambung Mangkurat \\ mhadinur23@gmail.com
}

\begin{abstract}
Abstrak
Indonesia merupakan Negara yang memiliki sumber daya alam yang tidak dapat diperbaharui seperti sungai dimana sungai ini bisa memberikan manfaat bagi manusia dalam melakukan peningkatan usaha ekonomi seperti budidaya ikan nila yang ada di indoneis, provinsi Kalimantan selatan, kabupatan Banjar,kecamatan karang intan, khususnya didesa mali-mali, dengan adanya sungai semua masyarakat rata-rata mempunyai usaha budidaya ikan dan sebagai penghasil peningkatan produksi ekonomi. Budidaya ikan nila udah menjadi prioritas masyarakat dibantaran sungai karena penghasilannya yang cukup memuaskan bagi masyarakat mali-mali, dan akhir-akhir ini dengan tersebar luasny covid 19 penghasilan produksi ekonomi budidaya ikan nila sangat berkurangnya dan sangat turun drastic penghasilan ekonomi masyarakat didesa mali-mali. Sungai sebagai salah satu dari bentuk ekosistem dengan potensi besar untuk digunakan sebagai tempat produksi budidaya ikan nila
\end{abstract}

Kata kunci: budidaya ikan nila, peningkatan produksi ekonomi, bantaran sungai

\section{PENDAHULUAN}

sumberdaya alam yang merupakan salah satu modal dasar dalam pembangunan. Sebagai modal dasar, sumberdaya alam harus dimanfaatkan sepenuhnya. Kita harus mengetahui cara -cara yang tepat dalam mengelolanya agar kita dapat memanfaat maksimal dan mengembangkan modal dasar tersebut makin besar manfaatnya, untuk pembangunan lebih di masa yang akan datang. Sebagai salah satu contoh dalam memanfaatkan sumber daya alam adalah membudidayakan dan memproduksi ikan, salah satu contohnya adalah ikan nila

Usaha budidaya ikan dengan cara sistem keramba jaring apung di Kabupaten Banjar , kecamatan karang intan,desa Mali-Mali memanfaatkan sumber mata air dari waduk Riam Kanan.Waduk Riam Kanan adalah sebuah danau/waduk yang berada di Kalimantan Selatan dan dibendung sebagai pembakit listrik tenaga air dan memberikan penghasilan bagi masyarakat untuk membudidayakan ikan nila 
Budidaya ikan Nila disukai karena ikan Nila mudah dipelihara, laju pertumbuhan dan perkembangbiakannya cepat, serta tahan terhadap gangguan hama dan penyakit. Selaindipelihara di sungai biasa seperti yang umum dilakukan, Ikan Nila juga dapat dibudidayakan disungai air yang deras, kantong jaring apung, karamba, dan sawah. Salah satu daerah yang potensial untuk budidaya ikan Nila di Indonesia provisi Kalimatan Selatan di kabupaten Banjar didesa mali-mali

Budidaya Ikan Air Tawar Kebutuhan ikan untuk konsumsi terus ditingkatkan namun terkendala oleh lahan yang tersedia. Keberhasilan usaha budidaya ikan air sangat ditentukan oleh konstruksi tambak, desain dan tata letak tambak, pengolahan tanah dan pengadaan benih saja, juga ditentukan oleh proses pemeliharaan sejak penebaran sampai pemungutan hasil (panen). Kegiatan yang perlu dilaksanakan selama periode pemeliharaan berlangsung antara lain pemberian pakan untuk organisme yang dibudidayakan. Pemberian pakan tambahan dalam jumlah yang cukup banyak, kemungkinan akan meninggalkan sisa-sisa yang apabila membusuk akan berpengaruh terhadap kualitas air. Oleh karena itu, pemberian pakan harus dilakukan dengan efisien (Kartadisastra 2003).

\section{PEMBAHASAN}

Usaha perikanan bukanlah usaha yang hanya sekedar melakukan kegiatan pemeliharaan ikan di kolam, di sungai, di danau, atau di laut, melainkan usaha yang mencakup berbagai aspek organisme (sumber hayati). Usaha perikanan di Indonesia dapat dikembangkan secara berkelanjutan. Selain perikanan di laut, kita mempunyai perairan di darat berupa danau, sungai, dan rawa. Usaha perikanan dapat dibagi dua jenis, yaitu usaha perikanan darat dan perikanan laut. Usaha perikanan darat disebut juga usaha perikanan air tawar (Evy, 1997). Meskipun tergolong relatif mudah, budidaya ikan nila tetap memerlukan penanganan yang baik dan terencana.

Hal yang pertama kali perlu dipersiapkan adalah pemilihan lokasi usaha karena dengan memilih/menyiapkan lokasi usaha yang tepat diharapkan usaha tersebut akan berjalan seperti yang diharapkan. Pemilihan lokasi usaha harus mempertimbangkan beberapa aspek, seperti aspek teknis ( berkaitan dengan teknis lahan sebagai wadah budidaya ikan baik air sungai nya), aspek ekonomi (ekonomis terkait dengan pendukung pemasaran dan biaya produksi), dan faktor social (berkaitan dengan daya terima masyarakat sekitar lokasi budidaya ikan). sehingga selama proses budidaya tidak akan ditemui kendala yang akan menghambat usaha tersebut.

Menurut Wahyurini (2005), pentingnya lahan tambak sebagai salah satu alternatif pengembangan budidaya ikan nila merah (Oreochromis niloticus) dari air tawar ke air payau. Saat ini belum diketahui secara jelas sejauh mana pengaruh 
salinitasnya terhadap pertumbuhan dan kelangsungan hidup sebagai indikator biologis adaptasi dalam proses osmoregulasi ikan nila, maka perlu dilakukan penelitian tentang "Pengaruh Perubahan Salinitas Yang Berbeda Terhadap Pertumbuhan Dan Tingkat Kelangsungan Hidup Benih Ikan Nila Merah

\section{Bagaimanakah Pemasaran ikan nila didesa Mali-Mali}

\section{Dijual ke Pedagang Pengepul (Pengumpul)}

Dia akan datang ke anda. Kelebihannya adalah pengepul umumnya siap kapanpun anda punya akan, hanya saja harganya akan jauh lebih miring .Pengepul akan mengambil ikan ke kolam sehingga tidak perlu repot. Dia harus memastikan Ikan nila yang diambil sesuai dengan pesanan pedagangnya Misal Harga di pasar 30.000 per Kg, harga di pengepul biasanya 25.000 per $\mathrm{kg}$. Selisih ini diklaim pengepul karena dia menanggung biaya bensin dan harus mendistribusikan ke pengecer. Mereka juga menanggung jika ikan tidak laku laku.Meski harga jualnya tidak tinggi, teknik ini paling banyak digemari.

2. Di jual ke pedagang pengecer di pasar dan toko.

Dimana seorang penjual ikan nila bisa di ecerkan di pasar atau di toko ini lebih memudahkan juga buat menjual ikan nila dan lebih baik nya Ig Bekerja sama dengan petani lain. lya anda cukup bekerja sama dengan petani lain agar bisa menyediakan ikan nila segar sepanjang tahun kepada penjual pasar agar sang penjual tidak kehabisan stok nya

3. Dijual ke Pemilik Warung Makan, Katering nasi,, atau Restoran.

Bisa juga ikan nila dijual belikan di ditempat pemilik warung makan atau restoran biar lebih memudahkan menjual ikan nila

4. Dijual sendiri

Dimana kalo kita Cukup kabari tetangga bahwa anda menjual ikan nila. Kabari ibu ibu tetangga dan para pembantu rumah tangga. Mereka akan senang bila mendapat nila murah tanpa harus ke pasar. Titip juga ke tukang sayur dan paman penjual ikan keliling.

5.dijual dikota2 dan didaerah terdekat

Ikan nila ini juga dipasarkan ke luar kota dan daerah terdekat kalo diluar kota bisa di batu licin, sungai danau, rantau, Kapuas,dan didaerah terdekat bisa di daerah Martapura,Astambul dan Banjarmasin,

Setelah adanya covid 19 produksi budidaya ikan nila sangat merosot murah harganya karena tidak banyak lagi pembeli yang berdatangan untuk membeli ikan nila, 
Gejala-gejala inilah yang kemudian melanda setiap denyut nadi kehidupan bangsa ini dengan rasa kekhawatiran yang tinggi, dimana kita dapat melihat dengan jelas setiap hari selalu hadir dalam wujud konflik sosial, dan kontradiksi sosial sebagai respon atas gejala tersebut (Abbas, E. W. 2018). Adanya konflik sosial sangat berat masyarakat dalam melakukan memproduksi budidaya ikan nila. Pemutusan hubungan kerja (PHK) menjadi langkah efektif bagi perusahaan untuk mengurangi kerugian perusahaan yang semakin bertambah. (Syaharuddin, S. 2020).

krisis ekonomi dengan meningkatkan kreativitas orang-orang di dalamnya untuk menciptakan produk yang unik dan kusus sehingga tidak bersaing dengan produk dari usaha-usaha besar lainnya. (Subiyakto, B., \& Mutiani, M. 2019). Memproduksi budidaya ikan nila harus memiliki kreativitas yang tinggi agar menghasilakn peningkatan ekonomi yang bagus dan berdaya saing dengan produk-produk dari usaha-usaha lainnya

Pembenihan dan pemeliharaan bibit ikan nila

Ciri-ciri induk bibit nila yang unggul adalah sebagai berikut:

Mampu memproduksi benih dalam jumlah yang besar dengan kwalitas yang tinggi. Pertumbuhannya sangat cepat. Sangat responsif terhadap makanan buatan yang diberikan. Adapun ciri-ciri ikan nila Bagian bawah tutup insang berwarna putih, sedangkan pada nila lokal putih agak kehitaman bahkan ada yang kuning. Sisik ikan nila besar, kasar, dan tersusun rapi. Sepertiga sisik belakang menutupi sisi bagian depan. Tubuhnya memiliki garis linea lateralis yang terputus antara bagian atas dan bawahnya. Linea lateralis bagian atas memanjang mulai dari tutup insang hingga belakang sirip punggung sampai pangkal sirip ekor. Ukuran kepalanya relatif kecil dengan mulut berada di ujung kepala serta mempunyai mata yang besar (Merantica 2007).

Menurut Peter (1979) dalamSetiawati dan Suprayudi (2003), salinitas merupakan salah satu faktor lingkungan yang dapat mempengaruhi laju pertumbuhan dan konsumsi pakan,Resisten terhadap serangan hama, parasit dan penyakit. Dapat hidup dan tumbuh baik pada lingkungan perairan yang relatif buruk. Ukuran induk yang baik untuk dipijahkan yaitu 120-180 gram lebih per ekor dan berumursekitar 4-5 bulan. Adapun ciri-ciri untuk membedakan induk jantan dan induk betina adalah sebagai berikut:

\section{a. Betina}

Terdapat 3 buah lubang pada urogenetial yaitu: dubur, lubang pengeluaran telur danlubang urine.

1.Ujung sirip berwarna kemerah-merahan pucat tidak jelas.

2.Warna perut lebih putih. 
3.Warna dagu Jika perut distriping tidak mengeluarkan cairan.

b. Jantan

1. Pada alat urogenetial terdapat 2 buah lubang yaitu: anus dan lubang spermamerangkap lubang urine.

2. Ujung sirip berwarna kemerah-merahan terang dan jelas.

3. Warna perut lebih gelap/kehitam-hitaman.

4. Warna dagu kehitam-hitaman dan kemerah-merahan.

Jika perut distriping mengeluarkan cairan. Ikan nila sangat mudah kawin silang dan bertelur secara liar. Akibatnya, kepadatankolam meningkat. Disamping itu, ikan nila yang sedang beranak lambat pertumbuhansehingga diperlukan waktu yang lebih lama agar dicapai ukuran untuk dikonsumsi yangdiharapkan. Untuk mengatasi kekurangan ikan nila di atas, maka dikembang metode kulturtunggal kelamin (monoseks). Dalam metode ini benih jantan saja yang dipelihara karenaikan nila jantan yang tumbuh lebih cepat daripada ikan nila betina.

Ada empat cara untuk memproduksi benih ikan nila jantan yaitu:

a.Secara manual (dipilih)

b. Sistem hibridisasi antarjenis tertentu

c. Merangsang perubahan seks dengan hormon

d.Teknik penggunaan hormon seks jantan ada dua cara.

1. Perendaman

2.Perlakuan hormone

.Peralatan dalam pembuatan tambak apung jaring

Peralatan ini digunakan untuk membuat tambak ikan nila dan hal-hal berkaitan lainnya. Tentunya peralatan merupakan hal yang penting jika ingin budidaya ikan nila karena berguna untuk pembuatan tambak nya, pemeliharaan tambak dan ikan nila, hingga saat panen nantinya. Oleh karena itu, pelaku budidaya ikan nila sebaiknya membuat daftar terlebih dahulu peralatan apa saja yang dibutuhkan. Pada umumnya, peralatan yang dibutuhkan untuk budidaya ikan nila

yaitu, jarring, kayu Ulin,baut,paku, drum, teng jerigen,dan pasir sebagai pemberat teng jerigen nya dan tambak nya berbentuk persegi panjang.

Makanan ikan nila 
Berdasarkan macam makanannya, ikan dapat dibedakan menjadi 5 golongan, yaitu :

1. Pemakan tumbuh-tumbuhan

2. Pemakan daging

3. Pemakan segala

4. Pemakan plankton

5. Pemakan hancuran bahan organik

Walaupun sudah diketahui bahan baku yang digunakan dalam pembuatan pakan mengandung protein yang tinggi dan baik. Pakan ikan dikatakan bermutu apabila setelah diproses dan dibuat juga mengandung nilai nutrisi dan gizi yang dibutuhkan oleh ikan. Menurut Murtidjo, (2001), ikan cepat besar dan akan lebih cepat di produksi

\section{SIMPULAN}

Budidaya kali ini adalah budidaya Ikan Nila yang biasa dibudidaya ditambak. Dan untuk harga dipasaran cukup murah tidak begitu mahal. Dan untuk jangka masa panen biasanya mencapai 4 bulan, tidak perlu memerlukan banyak biaya untuk pakannya. Biasanya di pasaran berat Ikan Nila berkisar 200 - 300 gr tergantung besar kecilnya ikan tersebut. Ikan Nila biasanya di budidayakan di tambak, keramba sungai, air tenang, air deras, dan sawah, Untuk ukuran kolam biasanya memiliki lebar $10 \mathrm{~m}$ dan panjang $20 \mathrm{~m}$, dan tinggi kolam $75 \mathrm{~cm}$. Ciri - ciri Ikan Nila jantan dan betina memilik perbedaan masing -masing, yakni :

1. Ikan Nila Jantan

Mempunyai 2 lubang yakni anus dan lubang sperma

Perut gelap

Ujung sirip merah, jelas, dan terang

Jika perut ditekan mengeluarkan cairan

Dagu berwarna hitam

2. Ikan Nila Betina

Ujung sirip merah / pucat

Perut terang

Mempunyai 3 lubang, yakni pengeluaran telur, urin, dan anus 
Begitu pula pemberian pakan pada ikan nila diberi 2 - 4 kali sehari

\section{DAFTAR PUSTAKA}

Abbas, E. W. (2018). Penguatan Pendidikan IPS Di Tengah Isu-Isu Global.

Jumriani, J. (2018). KEGIATAN PRODUKSI DAN DISTRIBUSI DI KAMPUNG SASIRANGAN SEBAGAI SUMBER BELAJAR IPS. Jurnal Socius, 7(1).

Kartadisastra, H. R. 1997. Penyediaan dan Pengolahan Pakan Ternak Ruminansia. Kanisius, Yogyakarta Evy, R., 1997. Usaha Perikanan di Indonesia. Mutiara Sumber Widya, Jakarta. Gunawan, D., 2011

Merantica, W. (2007). Pemanfaatan Meat and Bone Meal (MBM) Sebagai Penganti Tepung Ikan pada Pakan Ikan Nila.[Skripsi]. Bogor: Fakultas Perikanan dan Ilmu Kelautan. Institut Pertanian Bogor.

Mudjiman A., 2007. Makanan Ikan Edisi Revisi. Penebar Swadaya, Jakarta.

Murtidjo, B. A., 2001. Pedoman Meramu Pakan Ikan. Kanisius: Yogyakarta.

Putro, H. P. N., \& Jumriani, J. (2020). KEHIDUPAN SOSIAL DAN EKONOMI MASYARAKAT BANTARAN SUNGAI A SEBAGAI SUMBER BELAJAR IPS [Laporan Penelitian]. Universitas Lambung Mangkurat.

Sendjaja, J.T. dan M.H. Riski., 2002. Usaha Pembenihan Gurami. Penebar Swadaya, Jakarta.

Setiawati M dan Suprayudi A. M., 2003. Pertumbuhan dan efisiensi pakan ikan nila merah yang dipelihara pada media bersalinitas.[Jurnal]. jurusan Budidaya Perairan. Fakultas Perikanan dan Ilmu Kelautan. IPB. Bogor

Subiyakto, B., \& Mutiani, M. (2019). EKSISTENSI USAHA PEMBUATAN JUKUNG DI PULAU SEWANGI, ALALAK, BARITO KUALA.

Syaharuddin, S. (2020). PEMBELAJARAN MASA PANDEMI: DARI KONVENSIONAL KE DARING. PEMBELAJARAN MASA PANDEMI: DARI KONVENSIONAL KE DARING.

Wahyurini T.E., 2005. Pengaruh Perbedaan salinitas Air Terhadap Tingkat Kelangsungan Hidup benih Ikan Nila Merah (Oreochromis niloticus).[Jurnal]. Porgram Studi Agrobisnis perikanan. Fakultas Pertanian Universitas Islam Madura 
